\title{
PENGEMBANGAN E-BOOK INTERAKTIF SEBAGAI SUMBER BELAJAR MANDIRI PADA MATERI PEMUAIAN KELAS VII SMP/MTS
}

\author{
Aretha Amalia, Dinar Maftukh Fajar \\ *Program Studi Tadris IPA, Universitas Islam Negeri KH Achmad Siddiq Jember \\ *Corresponding Author: dinarfisika@gmail.com
}

DOI: $10.35719 /$ vektor.v2i2.46

\begin{abstract}
Abstrak. Pengembangan e-book interaktif sebagai sumber belajar mandiri pada materi Pemuaian kelas VII SMP/MTs dilakukan berdasarkan permasalahan yang terjadi di salah satu SMP negeri di Songgon, Banyuwangi, Jawa Timur, Indonesia. Selama proses pembelajaran secara online pada materi pemuaian, guru IPA menggunakan buku paket/cetak dan video pembelajaran, namun siswa masih kesulitan memahami materi dari kedua sumber tersebut. Salah satu penyebabnya ialah karena kurang interaktifnya sumber-sumber belajar tersebut. Tujuan dari penelitian ini yakni mendeskripsikan hasil validasi serta respons siswa terhadap e-book interaktif sebagai sumber belajar mandiri pada materi Pemuaian kelas VII SMP/MTs. Desain penelitian dan pengembangan menggunakan model 4D Thiagarajan di mana terdiri 4 tahap di antaranya, define, design, develop, serta disseminate, tetapi penelitian ini terbatas pada tahap develop. Subjek dalam penelitian ini terdiri atas 2 dosen UIN KHAS Jember sebagai ahli materi serta media, 2 guru IPA sebagai ahli pengguna serta uji respons dilakukan pada 32 siswa. Hasil validasi para ahli dan pengguna didapati rata-rata sebesar $92,5 \%$ dan $92,43 \%$, hal tersebut menunjukkan bahwa e-book interaktif sebagai sumber belajar mandiri dinyatakan sangat valid untuk digunakan. Hasil respons siswa memiliki rata-rata skor 90,58\%. Deskripsi respons siswa dijelaskan dalam bentuk wordcloud di mana sebagian besar siswa menilai bahwa e-book interaktif yang dikembangkan "bagus" karena terdapat tulisan, gambar, video, animasi, serta simulasi praktikum.
\end{abstract}

Kata Kunci: e-book interaktif, pemuaian, sumber belajar mandiri

\begin{abstract}
The development of an interactive e-book as a source of self-learning on the material thermal expansion of the class VII SMP/MTs was carried out based on problems in one of the junior high schools in Songgon, Banyuwangi, East Java, Indonesia. During the online learning process on thermal expansion material, science teachers used printed textbooks and learning videos, but students still had difficulty understanding the material from these two sources. One of the reasons is the lack of interactivity of both sources. The purpose of this study is to describe the results of the validation and student responses to the interactive e-book as a source of self-learning in the VII grade junior high school on thermal expansion material. The research and development design uses Thiagarajan's 4D model, which consists of 4 stages: define, design, develop, and disseminate, but this research is limited to the develop stage. The subjects in this study consisted of 2 lecturers of UIN KHAS Jember as material, and media experts, 2 science teachers as user experts, and the response test was carried out on 32 students. The expert and user validation results were found to be an average of $92.5 \%$ and $92.43 \%$, respectively; it shows that interactive e-book as a selflearning resource is declared very valid to be used. The results of student responses have an average score of $90.58 \%$. Descriptions of student responses are explained in the form of word cloud, where most students consider that the interactive e-book developed is "good" because it is equipped with writing, pictures, videos, animations, and practical simulations.
\end{abstract}

Keywords: interactive e-book, self-learning, thermal expansion

\section{PENDAHULUAN}

Ilmu Pengetahuan Alam atau disingkat dengan IPA ialah ilmu yang mengkaji fenomena alam yang diperoleh secara indrawi maupun pengalaman yang berupa fakta, 
konsep, serta hukum yang didukung oleh berbagai penelitian (Fitriyati \& Hidayat, 2017). IPA sendiri memiliki beberapa cabang ilmu yang dipelajari di sekolah di antaranya yaitu biologi, kimia, fisika, astronomi/astrofisika, serta geologi (Wisudawati \& Sulistyawati, 2017). Dalam mata pelajaran IPA di tingkat SMP, salah satu topik bahasan yang dipelajari ialah materi Pemuaian. Materi ini membahas Pemuaian zat padat, zat cair, dan zat gas. Masalah yang biasa ditemui dalam materi Pemuaian ini ialah kurangnya pemahaman konsep sehingga siswa sulit memahami dan memecahkan masalah pada pelajaran berikutnya, karena materi Pemuaian merupakan materi yang berkelanjutan (Nurussaniah dkk., 2017). Hal ini menunjukkan bahwa peran guru sangatlah penting dalam menyampaikan materi untuk membantu siswa memahami materi yang disajikan.

Proses belajar di masa pandemi Covid-19 sekarang, tetap dilakukan dengan menggunakan berbagai macam media di antaranya dapat berupa media cetak dan media digital yang dimanfaatkan oleh guru secara daring. Pembelajaran daring ialah pembelajaran jarak jauh dengan aktivitas virtual, pembelajaran daring ini sendiri memungkinkan guru dengan siswa untuk memanfaatkan media elektronik untuk berlangsungnya proses belajar mengajar (Kurniawan dkk., 2020). Berdasarkan hasil wawancara dengan dua orang guru IPA dari salah satu SMP negeri di Songgon, Banyuwangi, Jawa Timur, Indonesia diketahui bahwa saat kegiatan pembelajaran secara daring guru masih menggunakan buku paket/cetak dan video pembelajaran dalam menunjang kegiatan pembelajaran. Namun penggunaan sumber belajar tersebut kurang efektif, karena menyulitkan siswa dalam memahami materi yang sedang dijelaskan. Di samping itu, berdasarkan angket yang dihimpun dari 25 siswa juga ditemukan permasalahan berupa kurang adanya keterhubungan antara materi pada buku paket dan materi pada video pembelajaran sehingga membuat hal ini kurang praktis dan kurang interaktif, terutama pada pembahasan tentang rumus dan perhitungan.

Dalam mengatasi permasalahan tersebut, guru perlu lebih kreatif dan inovatif dalam menentukan sarana/media dalam kegiatan pembelajaran. Media pembelajaran sendiri ialah sarana, perlengkapan, serta strategi yang digunakan untuk menyampaikan informasi, merangsang penalaran, perasaan, ketertarikan serta minat siswa yang ada pada dirinya (Aditya, 2018; Shalikhah dkk., 2017). Seperti halnya sumber belajar siswa, saat ini buku tidak hanya berbentuk cetak akan tetapi dapat juga berupa e-book, di mana e-book merupakan buku teks dalam format digital (Bayani, 2019). Menurut Hidayat dkk. (2017), e-book memiliki beberapa kelebihan di antaranya biaya yang dikeluarkan rendah, mudah dibawa, ruang penyimpanan praktis seperti laptop dan smartphone, serta dapat didesain lebih interaktif. Untuk dapat membuat e-book lebih menarik dan interaktif, perancang dapat menggunakan salah satu software yakni Flip PDF Corporate Edition. Software tersebut digunakan dalam pembuatan sumber belajar dengan megkonversi format word menjadi flipbook. Selain itu aplikasi ini juga dapat menambahkan beberapa elemen seperti video, animasi, dan multimedia lainnya (Purwanto dkk., 2020).

Penggunaan e-book interaktif diharapkan mampu dimanfaatkan sebagai sumber belajar mandiri yang mampu menambah wawasan siswa dengan ataupun tanpa bantuan orang lain. Seperti yang dijelaskan oleh Januszewski \& Molenda (2010), bahwa sumber belajar merupakan suluruh informasi yang diperoleh dari pesan, orang, bahan, media, metode, anggaran, sarana, serta latar yang dapat dimanfaatkan secara berkelompok maupun individu untuk mengakomodasi proses pembelajaran serta meningkatkan kemampuan diri dalam belajar. Sumber belajar mandiri diharapkan mampu meningkatkan proses pembelajaran siswa, seperti yang dijelaskan oleh Oxford Brookes University bahwa pembelajaran mandiri merupakan suatu proses, metode, serta filosofi pembelajaran di mana seorang siswa mendapat ilmu dengan usaha sendiri serta membangun kemampuan untuk menyeldiki serta evaluasi kritis (Yuen dkk., 2018).

Penelitian tentang pengembangan buku elektronik sebagai sumber belajar mandiri telah dilakukan oleh berbagai pihak. Satu di antaranya ialah Udin dkk. (2017) yang telah berhasil mengembangkan e-book interaktif yang layak untuk pembelajaran pada materi 
Teori Relativitas Khusus. Selanjutnya, menurut Santi dkk. (2018), hasil penelitiannya menunjukan buku elektronik inti atom dapat dioperasikan secara mandiri. Hal yang sama dinyatakan oleh Prihata (2019) bahwa buku elektronik yang telah dikembangkan dapat digunakan secara efektif sebagai sumber belajar mandiri serta mampu meningkatkan keterampilan berpikir kritis siswa. Penulis menganalisis belum ditemukan penelitian pengembangan e-book interaktif pada materi Pemuaian sebagai sumber belajar mandiri khususnya pada pembelajaran daring pada masa pandemi.

Berdasarkan penjelasan di atas, penulis merumuskan judul "Pengembangan E-book Interaktif Sebagai Sumber Belajar Mandiri Pada Materi Pemuaian Kelas VII SMP/Mts." Tujuan yang hendak dicapai antara lain, mendeskripsikan hasil validasi serta respons siswa terhadap e-book interaktif sebagai sumber belajar mandiri pada materi Pemuaian kelas VII SMP/MTs.

\section{METODE}

Penelitian dan pengembangan ini menggunakan tahapan 4D Thiagarajan, yakni define, design, develop, serta disseminate (Sugiyono, 2015). Penelitian ini dibatasi hingga tahap develop. Mekanisme penelitian ditampilkan pada gambar 1.

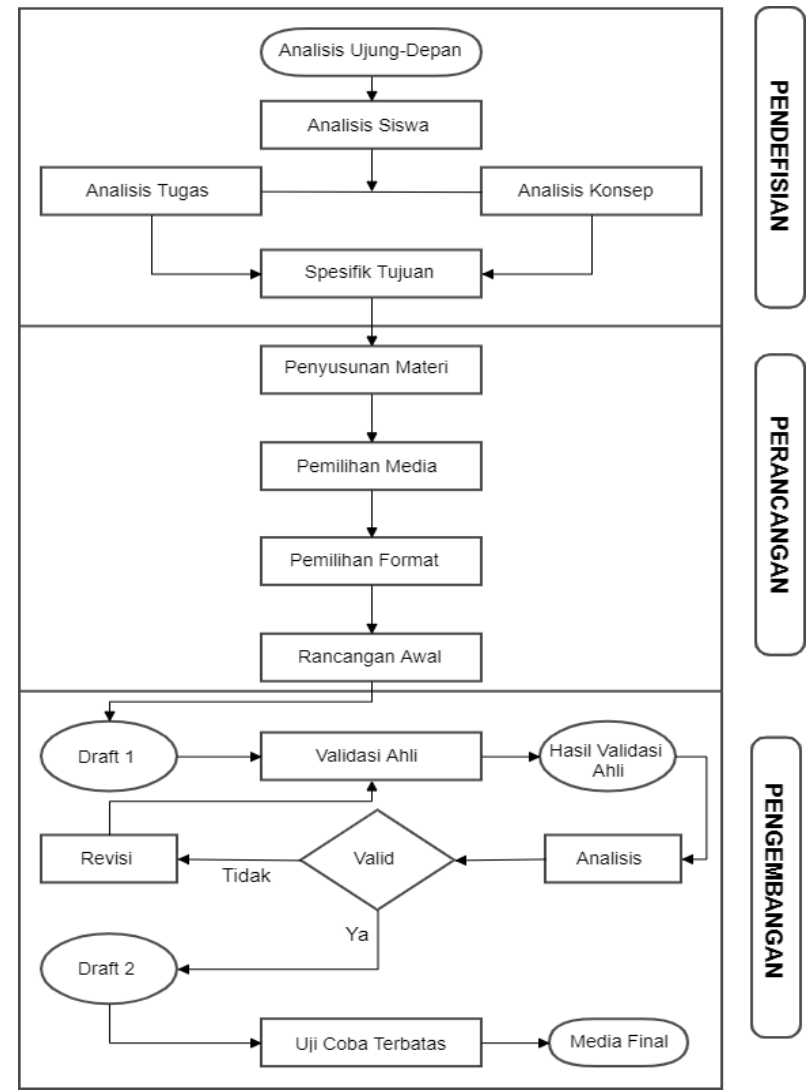

Gambar 1. Prosedure model 4D Thiagarajan

Subjek penilaian pada e-book interaktif yang dikembangkan meliputi dua dosen UIN KH Achmad Siddiq Jember sebagai ahli materi dan media, serta dua guru IPA di SMPN 1 Songgon, Banyuwangi, Jawa Timur, Indonesia. Uji respons siswa dilakukan pada 32 siswa kelas VII SMPN 1 Songgon, Banyuwangi, Jawa Timur, Indonesia.

Pada penelitian ini, instrumen pengumpulan data menggunakan angket validasi serta respons siswa. Data hasil penelitian dan pengembangan ini dianalisis dalam bentuk analisis data kualitatif serta kuantitatif. Dalam analisis data kualitatif, bukan hanya kritik serta saran dari para ahli serta pengguna, melainkan juga diperoleh dari respons siswa 
yang divisualisasikan ke dalam bentuk wordcloud dengan menggunakan aplikasi Orange Data Meaning. Penggunaan wordcloud membantu memvisualisasikan kata-kata dalam term dokumen menjadi lebih menarik (Pradana, 2020), selain itu dalam visualisasi wordcloud kata yang sering muncul dalam topik ditampilkan lebih menonjol sehingga lebih mudah untuk dipahami serta intuitif (Sahria, 2020). Kemudian pada analisis data kuantitatif berasal dari skor persentase untuk mengetahui kevalidan serta kemenarikan dari e-book interaktif yang dikembangkan. Berikut teknik analisis data validitas serta kemenarikan secara berurutan menggunakan persamaan (1) dan (2) sebagai berikut (Akbar, 2017).

$$
V-a h=\frac{T S e}{T S h} \times 100 \%
$$

Hasil perhitungan ditafsirkan dalam bentuk skor atau persentase (Akbar, 2017) seperti pada Tabel 1 dan Tabel 2.

Tabel 1. Kriteria validaitas

\begin{tabular}{cc}
\hline Kriteria Validitas & Tingkat Validitas \\
\hline $85,01 \%-100 \%$ & Sangat Valid \\
\hline $70,01 \%-85,01 \%$ & Valid \\
\hline $50,01 \%-70,01 \%$ & Kurang Valid \\
\hline $0,1 \%-50,00 \%$ & Tidak Valid \\
\hline & \\
$V-a u=\frac{T S e}{T S h}$ & \\
\end{tabular}

Tabel 2. Kriteria kemenarikan

\begin{tabular}{cc}
\hline $\begin{array}{c}\text { Kriteria Pencapaian } \\
\text { Nilai }\end{array}$ & Tingat Kemenarikan \\
\hline $81,00 \%-100,00 \%$ & Sangat Menarik \\
\hline $61,00 \%-80,00 \%$ & Menarik \\
\hline $41,00 \%-60,00 \%$ & Cukup Menarik \\
\hline $21,00 \%-40,00 \%$ & Tidak Menarik \\
\hline $00,00 \%-20,00 \%$ & Sangat Tidak Menarik \\
\hline
\end{tabular}

\section{HASIL DAN PEMBAHASAN}

\section{Define (Pendefinisian)}

Tahap define dilakukan bertujuan untuk mendeskripsikan serta menetapkan suatu produk yang dikembangkan berdasarkan analisis kebutuhan. Tahap ini dilakukan dengan mewawancarai dua guru IPA serta menyebarkan angket kepada 25 siswa kelas VII SMPN 1 Songgon, Banyuwangi, Jawa Timur, Indonesia tahun pelajaran 2020/2021. Dari hasil wawancara diketahui bahwa kegiatan pembelajaran dilakukan secara online dengan bantuan WA group. Untuk dapat menunjang kegiatan belajar dalam setiap pembelajaran guru masih menggunakan buku paket/cetak dan video pembelajaran. Namun penggunaan kedua media tersebut masih di anggap kurang efektif, hal ini mengakibatkan siswa merasa kesulitan dalam memahami materi.

Setelah menyebarkan angket terhadap 25 siswa diperoleh bahwa sekitar $84 \%$ siswa masih mengalami kesulitan dalam pelajaran fisika, sedangkan sekitar $16 \%$ tidak mengalami kendala. Selain itu, dalam menunjang kegiatan pembelajaran masih menggunakan buku paket serta video pembelajaran, namun penggunaan dari kedua media tersebut membuat siswa sulit untuk memahami materi yang di paparkan 
dikarenakan kurang paham serta merasa bingung dengan penjelasan yang dimuat disebabkan penjelasan materinya kurang.

\section{Design (Perancangan)}

Tahap design bertujuan untuk menentukan format e-book interaktif yang dikembangkan. Pada tahap ini, menyusun materi yang akan disajikan dengan acuan Kompetensi Inti (KI) serta Kompetensi Dasar (KD) K13 revisi 2018.

Dalam penyusunan e-book interaktif ini, penulis terlebih dahulu mengumpulkan gambar, animasi, serta informasi pendukung lain yang akan dimuat. Selanjutnya, materi serta informasi yang diperoleh terkumpul kemudian dibuat dan disajikan dalam bentuk $e-$ book yang mengacu pada BSNP menggunakan Ms. Word 2013, setelah itu dikonversikan ke dalam bentuk pdf. Agar dapat membuat e-book menjadi lebih interaktif, menggunakan software Flip PDF Corporate Edition yang nantinya di publish dalam bentuk link. berikut.

Adapun beberapa tampilan yang termuat dalam e-book interaktif yakni sebagai

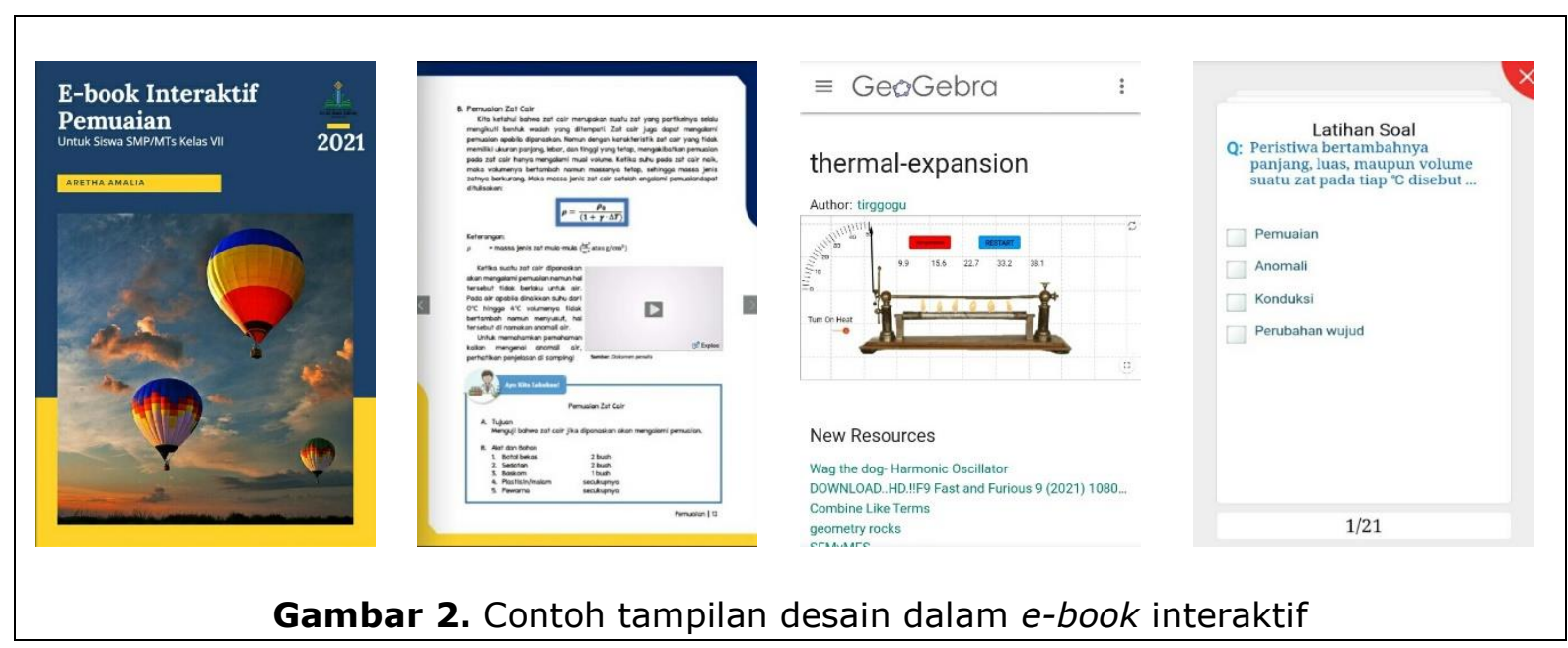

\section{Develop (Pengembangan)}

Tujuan tahap develop ialah untuk menghasilkan produk yang kemudian diujikan kevalidannya kepada para ahli serta kemenarikan terhadap respons siswa. Produk yang dikembangkan pada penelitian dan pegembangan ini yakni e-book interaktif sebagai sumber balajar mandiri pada materi pemuaian kelas VII SMP/MTs. Berikut akumulasi data dari hasil validasi ahli, pengguna serta respons siswa dengan menggunakan persamaan (1) dengan (2), sebagai berikut.

Tabel 3. Akumulasi data validasi ahli, pengguna, dan respons siswa

\begin{tabular}{clccc}
\hline No & \multicolumn{1}{c}{ Validator } & $\begin{array}{c}\text { Persentase } \\
(\mathbf{\%})\end{array}$ & Rata-rata & $\begin{array}{c}\text { Kategori } \\
\text { Validasi }\end{array}$ \\
\hline 1 & $\begin{array}{l}\text { Ahli } \\
\text { a. Ahli Materi } \\
\text { b. Ahli Media }\end{array}$ & $\begin{array}{l}93,89 \% \\
91,11 \%\end{array}$ & $92,5 \%$ & Sangat Valid \\
\hline \multirow{2}{*}{$\begin{array}{l}\text { Pengguna } \\
\text { a. Pengguna I } \\
\text { b. Pengguna II }\end{array}$} & $\begin{array}{l}90,93 \% \\
93,93 \%\end{array}$ & $92,43 \%$ & Sangat Valid \\
\hline \multirow{2}{*}{$\begin{array}{l}\text { Respons Siswa } \\
\text { a. Kelompok Kecil } \\
\text { b. Kelompok Besar }\end{array}$} & $90,63 \%$ & $90,58 \%$ & Sangat Menarik \\
\hline
\end{tabular}


Tabel 3 menunjukan bahwa hasil validasi ahli materi dan media ialah 93,89\% dan $91,11 \%$, dengan rata-rata $92,5 \%$. Hal ini menunjukkan e-book interaktif "sangat valid" sebagai sumber belajar mandiri dari aspek materi dan media. Selain itu adapun beberapa kritik serta saran yang di berikan oleh para ahli terhadap produk yang di kembangkan di antaranya adalah jumlah contoh soal dikaitkan dengan perkembangan yang ada dalam kehidupan sehari-hari, peta konsep perlu kata hubung antar konsep, pada awal e-book sebaiknya diberi petunjuk awal penggunaan e-book seperti apa, pada bagian gambar di beri penomoran, bagian simulasi praktikum sebaiknya diberi petunjuk penggunaan, bagian sapaan pada bagian cover belakang sebaiknya diletakan pada bagian awal e-book. Kemudian hasil validasi dari pegguna I dan II diperoleh 90,93\% dan 93,93\%, dengan rata-rata sebesar $92,43 \%$. Sehingga dari hal tersebut menunjukkan e-book interaktif dikategorikan "sangat valid" dari segi pengguna. Namun, terdapat beberapa kritik dan saran dari pengguna yakni masih terdapat penulisan yang typo sehingga lebih teliti dalam penulisan serta penambahan materi terapan dan materi motivasi untuk mengikuti perkembangan teknologi.

Uji respons kelompok kecil dilakukan dengan 6 siswa SMPN 1 Songgon, Banyuwangi, Jawa Timur, Indonesia di kelas VIII-A, hasil uji respons kelompok kecil diperoleh adalah 90,63\%. Pada uji respons kelompok besar dengan 32 siswa, hasil uji coba ialah 90,52\%. Rata-rata uji kelompok kecil dengan kelompok besar diperoleh $90,58 \%$. Hal ini menunjukkan bahwa e-book interaktif dinilai "sangat menarik" sebagai sumber belajar mandiri, untuk lebih jelasnya hasil akumulasi validasi ahli dan respons siswa dapat dilihat pada gambar diagram berikut ini.

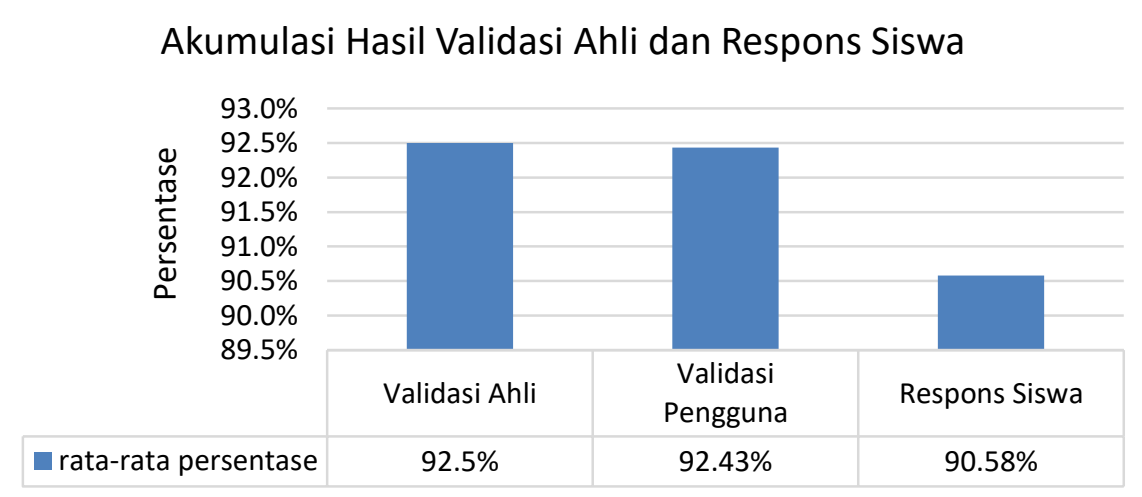

Gambar 3. Diagram akumulasi hasil validasi ahli, pengguna, dan respons siswa

Selain itu, siswa juga memberikan kritik dan sarannya terhadap e-book interaktif ini serta memberikan kesan negatif dan positif yang divisualisasikan dalam bentuk wordcloud yakni sebagai berikut.

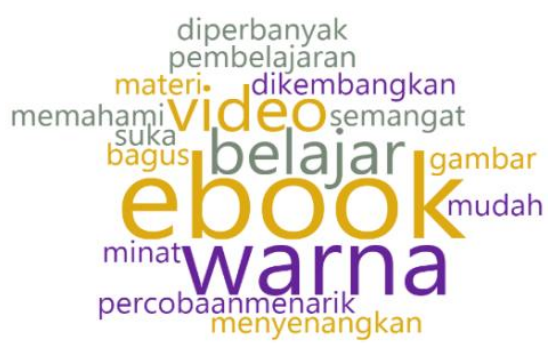

(a)

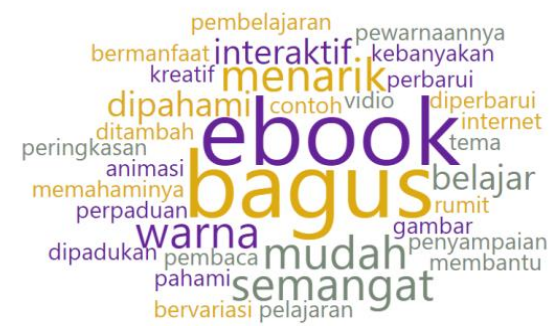

(b)

Gambar 4. Kritik dan saran respons siswa (a) kelompok kecil dan (b) kelompok besar 


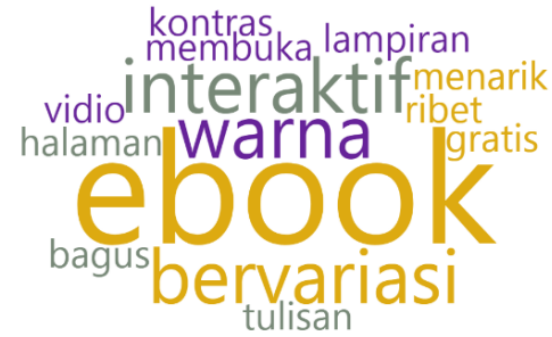

(a)

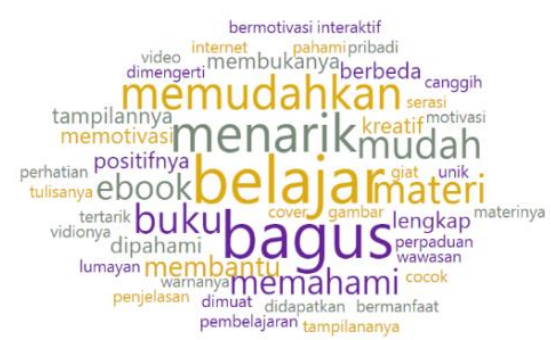

(b)

Gambar 5. Kesan (a) negatif dan (b) positif terhadap e-book interaktif sebagai sumber belajar mandiri

Pada gambar 4 menunjukkan e-book interaktif "bagus" menurut pendapat siswa, karena tidak hanya berisi tulisan, tetapi juga gambar, video, animasi, dan simulasi praktikum. Kemudian, gambar 5 menunjukkan bahwa e-book interaktif tidak hanya menarik serta bagus, tetapi juga memudahkan siswa untuk memahami materi yang disajikan.

Seperti yang dijelaskan oleh Sabtaningrum dkk. (2020) e-book ialah buku yang dimuat dalam bentuk digital yang berisi informasi dalam bentuk tulisan, gambar, video, audio, serta animasi, yang bertujuan untuk memvisualisasikan materi yang abstrak menjadi lebih nyata. Selain itu juga, sejalan dengan pendapat Lestari dkk. (2018) bahwa e-book interaktif adalah alat yang dimanfaatkan untuk membantu siswa memahami pembelajaran yang abstrak, di mana di dalamnya memuat teks, gambar, video, dalam satu kesatuan untuk menarik perhatian siswa dalam pembelajaran secara mandiri. Sedangkan menurut Saddhono dkk. (2019) menjelaskan penambahan beberapa konten multimedia dalam e-book interaktif juga memudahkan untuk memahami konsep yang disajikan.

Sehingga dari penjelasan tersebut dapat disimpulkan, e-book interaktif dikategorikan sangat valid serta sangat menarik untuk dijadikan sebagai sumber belajar mandiri dalam kegiatan pembelajaran.

\section{KESIMPULAN}

Hasil validasi oleh ahli materi memperoleh persentase sebesar 93,89\%, kemudian ahli media sebesar $91,11 \%$. Sehingga rata-rata dari para ahli ialah $92,5 \%$. Kemudian hasil validasi oleh ahli pengguna I dan II secara berturut-turut diperoleh persentase sebesar 90,93\% \& 93,93\%, rata-rata dari pengguna sebesar 92,43\%. Hal tersebut menunjukan bahwa e-book interaktif sebagai sumber belajar mandiri dinyatakan "sangat valid" untuk digunakan.

Pengembangan e-book interaktif juga di ujikan kepada siswa yakni, kelompok kecil dan besar. Hasil uji respons kelompok kecil diperoleh persentase 90,63\%, sedangkan pada kelompok besar diperoleh persentase 90,52\%. Rata-rata yang diperoleh dari resons siswa sebesar 90,58\%. Hal tersebut membuktikan bahwa e-book interaktif sebagai sumber belajar mandiri dinyatakan sangat "menarik" serta memudah siswa untuk memahami materi dengan mudah.

\section{UCAPAN TERIMAKASIH (Jika ada)}

Penulis mengucapkan terima kasih kepada SMPN 1 Songgon, Banyuwangi, Jawa Timur, Indonesia yang telah membantu serta memberikan fasilitas dalam melaksanakan penelitian ini. 


\section{DAFTAR PUSTAKA}

Aditya, P. T. (2018). Pengembangan Media Pembelajaran Matematika Berbasis Web Pada Materi Lingkaran Bagi Siswa Kelas VIII. Jurnal Matematika Statistika dan Komputasi, 15(1), 64.

Akbar, S. (2017). Instrumen Perangkat Pembelajaran. Remaja Rosdakarya.

Bayani, A. (2019). Pengembangan e-Book Matematika Berbasis Masalah Pada Materi Kubus Dan Balok SMP/MTs Kelas VIII. JPM: Jurnal Pendidikan Matematika, 5(1), 7.

Fitriyati, I., \& Hidayat, A. (2017). Pengembangan Perangkat Pembelajaran IPA Untuk Meningkatkan Kemampuan Berpikir Tingkat Tinggi dan Penalaran Ilmiah Siswa Sekolah Menengah Pertama. Jurnal Pembelajaran Sains, 1(1), 8.

Hidayat, A., Suyatna, A., \& Suana, W. (2017). Pengembangan Buku Elektronik Interaktif Pada Materi Fisika Kuantum Kelas XII SMA. Jurnal Pendidikan Fisika, V(2), 15.

Januszewski, A., \& Molenda, M. (2010). Educational Technology: A Definition with Commentary (Vol. 12). Routledge.

Kurniawan, R. A., Rifa'i, M. R., \& Fajar, D. M. (2020). Analisis Kemenarikan Media Pembelajaran PhET berbasis Virtual Lab pada Materi Listrik Statis Selama Perkuliahan Daring Ditinjau dari Perspektif Mahasiswa. VEKTOR: Jurnal Pendidikan IPA, 1(1), 19-28.

Lestari, R. T., Adi, E. P., \& Soepriyanto, Y. (2018). E-book Interaktif. Jurnal KajianTeknologi Pendidikan, 1(1), 71-76.

Nurussaniah, N., Wahyudi, W., \& Hidayati, N. S. (2017). Efektivitas Penggunaan Booklet Untuk Meremediasi Kesalahan Siswa Pada Materi Pemuaian Zat Di Kelas VII SMP Negeri 1 Tangaran Kabupaten Sambas. Jurnal Edukasi Matematika dan Sains, $4(2), 96$.

Pradana, M. G. (2020). Penggunaan Fitur Wordcloud dan Document Term Matrix Dalam Text Mining. Jurnal Ilmiah Informatika, 8(1), 38-43.

Prihata, L. (2019). Pengembangan Buku Elektronik Interaktif Pada Materi Sumber Daya Energi Untuk Belajar Mandiri Dan Menumbuhkan Kemampuan Berpikir Kritis Siswa [Tesis]. Univertas Lampung.

Purwanto, A., Nurjayadi, M., \& Tantaruna, J. E. (2020). Pengembangan e-Modul Elektrokimia Terintergasi Lingkungan Berbasis Kontekstual Untuk SMK Kompetensi Keahlian Teknik Otomotif. JRPK: Jurnal Riset Pendidikan Kimia, 10(1), 18-26.

Sabtaningrum, F. E., Wiyokusumo, I., \& Leksono, I. P. (2020). E-book Tematik Terpadu Berbasis Multikultural Dalam Kegiatan SFH (School from Home). Jurnal Ilmiah Sekolah Dasar, 4(2), 153. 
Saddhono, K., Sulaksono, D., \& Rahim, R. (2019). Pengembangan E-Book Interaktif BIPA Bermuatan Kearifan Lokal Dengan Pendekatan Scientific-Thematic. Konferensi Internasional Pengajaran Bahasa Indonesia bagi Penutur Asing (KIPBIPA) XI, 389401.

Sahria, Y. (2020). Implementasi Teknik Web Scraping pada Jurnal SINTA Untuk Analisis Topik Penelitian Kesehatan Indonesia. Proceeding of The URECOL, 297-306.

Santi, N. W., Suyatna, A., \& Suyanto, E. (2018). Pengembangan Buku Elektronik Inti Atom Sebagai Bahan Ajar Mandiri Untuk Menumbuhkan Kemampuan Berpikir Kritis Siswa. Jurnal Pendidikan Fisika, 6(2), 12.

Shalikhah, N. D., Primadewi, A., \& Iman, M. S. (2017). Media Pembelajaran Interaktif Lectora Inspire Sebagai Inovasi Pembelajaran. Warta LPM, 20(1), 9-16.

Sugiyono. (2015). Metode Penelitian \& Pengembangan (Research \& Development/R\&D). Alfabeta.

Udin, Y., Oktova, R., \& Sukmawati, S. S. (2017). Pemanfaatan Ms Excel 2010 Untuk Pengembangan Buku Elektronik Interaktif Tentang Transformasi Lorentz Dalam Pokok Bahasan Teori Relativitas Khusus Sebagai Sumber Belajar Mandiri Untuk Mahasiswa S-1 Pendidikan Fisika. Berkala Fisika Indonesia: Jurnal Ilmiah Fisika, 9(2), 13.

Wisudawati, A. W., \& Sulistyawati, E. (2017). Metodologi Pembelajaran IPA. Bumi Aksara.

Yuen, M.-C., Koo, A.-C., \& Woods, P. C. (2018). Independent Learning of Digital Animation: International Journal of Information and Communication Technology Education, 14(4), 107-120. 